\title{
An Optimal Tax Audit Mechanism: Models and Some Evidences
}

\author{
BAHK, JAE WAN \\ Assistant Director, Board of Audit and Inspection, Korea
}

\begin{abstract}
Since tax evasion, a moral hazard rooted in information asymmetry, causes inefficiency as well as distorting income distribution, conscious policies are needed to abate its harm. However, policy measures are limited-the penalty for tax evasion is bounded above and monitoring resources are constrained. Focusing on the selfemployed, we thus explore how to design a socially optimal tax audit mechanism. With the 1989 Korean 'Family Income and Expenditure Survey,' we also cxamine: (1) tax payment factors; (2) the income tax gap between self-employed (SELF) households (HHs) and 'pay-as-you-earn' (PAYE) employee HHs; and (3) the effect of the tax audit rule on compliance.

Though it saves audit resources and seizes evaders' risk premium, cutoff audit-currently adopted in Korea featuring 'reporting guidelines'-is shown to lower social welfare due to its built-in regressive bias. The line drawing hinders self-compliance as well. Endogenous audit with the audit chance declining in reported income without truncation is desirable for inequality-averse society. At least, the cutoff must be kept secret to taxpayers.

The empirical analysis shows: (1) One-third of SELF HHs and $90 \%$ of temporary employees in the nonfarm sector are beyond tax enforcement; (2) SELF HHs pay less income tax than PAYE HHs by 46-60\%, ceteris paribus, amounting to 18-30\% of income tax collection. The tax gap widens with income.; (3) The elasticity of income tax payment to income is less than one for SELF HHs, conflicting with progressive taxation; (4) SELF HHs' elasticity is lower around their mean income than at tails. This reflects the adverse effect of cutoff audit; and (5) Tax enforcement is ineffective to capital income.
\end{abstract}

\section{Introduction}

Tax evasion, a 'moral hazard' rooted in 'information asymmetry,' may be as old as The Korean Journal of Policy Studies Vol. 7 (1992), 55-72 
taxation. It is common across borders as well. Is tax evasion then a necessary evil? No doubt we must live with casual tax evasion and forego complete compliance due to costly enforcement. Tax evasion, however, causes extra inefficiency over the initial 'deadweight loss' from taxation as well as distorting intended income redistribution. Especially in Korea, where tax evasion appears to be widespread, ${ }^{1)}$ conscious policies are needed to abate its harm.

Since Becker (1968), it has been argued that the best deterrent against shirking is an infinite penalty with a very low probability of monitoring. This drastic policy is, however, desirable only in an exceptional case (e.g., during the wartime). ${ }^{2)}$ Nor is increasing the audit probability or audit intensity feasible because of the budget constraint.

Given the bounded penalty and the inflexible budget, this study explores, focusing on the self-employed, a natural question: how to design a socially optimal tax audit mechanism. With the Korean 'Family Income and Expenditure Survey' (FIES), it also examines: (1) tax payment factors; (2) the income tax gap between self-employed (SELF) households (HHs) and 'pay-as-you-earn' employee (PAYE) HHs; and (3) the effect of the tax audit rule on tax compliance.

Though it saves audit resources and confiscates evaders' risk premium, cutoff audit-currently adopted by the Korean National Tax Administration (NTA)-is shown to yield lower social welfare than others by distorting the marginal tax schedule with its built-in regressive bias. In addition, the line drawing hinders self-compliance.Endogenous audit with the audit chance declining in reported income is desirable for inequality-averse society.

The empirical analysis shows: (1) One-third of SELF HHs and 90\% of temporary employees in the nonfarm sector exist out of tax enforcement; (2) SELF HHs pay less income tax than PAYE HHs by $46-60 \%$, celeris paribus, which translate into $18-30 \%$ of income tax revenue. The gap widens with income; (3) The income elasticity of income tax payment is greater than one for PAYE HHs. But it is less than one for SELF HHs, conflicting with progressive taxation; and (4) For SELF HHs, the elasticity is lower around their mean income than at tails. This may reflect the adverse effect of cutoff audit.

The paper is organized into four sections. Following the introduction, Section 2 emulates three audit mechanisms to compare their welfare consequences. Section 3 infers tax-paying behavior of the two groups of HHs by jointly estimating their tax payment function with the FIES data. Section 4 concludes. 


\section{Models}

\section{N'A's Tax Audit Policy}

The NTA embraces a deterministic audit rule with two cutoffs for the selfemployed.One is the 'reporting guideline,'a minimum increase rate in reported gross receipts over the previous year's. The other is the 'income standard,' a proportion of income to gross receipts by which taxable income is estimated in case proper books are unavailable. Both, varying by the type and the area of business, are adjusted and made public semi-annually.

Once they comply with the two guidelines, the self-employed are exempt from the field audit. they thus tend to report income slightly above the threshold to secure an indulgence. Working as the 'second income tax rates' (Chang, 1991), the guidelines provide a safe harbor. In 1989 , liabilities of most (94.9\%) 'global income tax' filers were determined by these guidelines while only $2.9 \%$ of them suffered through the field audit (NTA, 1990: Table 2-1-4).

\section{Objectives and Constraints of Tax Enforcement}

As to the objective of tax enforcement, some issues arise. The most crucial one is whether to maximize social welfare or net revenue yield. Revenue maximization results in overenforcement as the Leviathan-like tax agency cares about neither benefits of tax cheating nor taxpayers' compliance cost. To avold this unsuitable feature, we elect to maximize social welfare.

Second, how averse should the social welfare function be to income inequality? Since our interest lies in enforcement instead of setting the tax schedute right, we view the current schedule as properly reflecting the optimum aversion agreed among taxpayers through some political process. Social welfare is then a function of the deviation of actual inequality from the target one. Third, should the utility of evaders count? If so, how much weight should be attached to them? As the answers require moral judgment, we leave out these questions and treat cheaters' utility no differently from conformers. 3 )

Summing up the above discussion, we define the social welfare function as:

$$
W=\int_{0}^{y^{b}} g\left(T^{*}-T\right) f(y) d y
$$

where y: pre-tax income which follows a cumulative distribution function $F(y)$ and a probability density $f(y)$, i.e., $F^{*}(y)=f(y), y \subseteq\left(0, y^{b}\right)$

$T^{*}$ : income tax liability which is strictly convex in income with an instant- 
aneously graduated marginal tax schedule, $0 \leq T^{* \prime}(y)<1$, and $T^{* \prime \prime}(y)>$ 0 ;

$T$ : tax paid as a function of policy parameters and income, i.e., $T=T(y, p(T(y))$, $\gamma, \tau(\mathrm{y}))$, and $0 \leq T \leq T^{*}$

$p$ : audit probability which depends on reported tax;

$\gamma$. fixed penalty (surcharge) rate for evaded tax;

$\tau$ : progressive marginal tax rate, i.e., $\tau(y)>0$;

$g(\cdot)$; welfare measure (with its maximum normalized at zero) which is strictly concave, i.e., $g^{\prime}<0$ and $g^{\prime \prime}>0$.

An implicit assumption above is $T^{*} \geq T$. This may not be true if: (1) an honest taxpayer bears significant costs associated with tax audit; and (2) reporting a slightly more income than actual substantially reduces the audit chance.4) For simplicity, we rule out this possibility.

On the other hand, the tax agency faces two constraints. First, it must raise a certain amount of revenue net of audit costs and fines collected, yielding the following budget constraint:

$$
\int_{0}^{y^{b}}\left[T+p\left(T^{*}-T\right)(1+\gamma)-p a\right] f(y) d y \geq B
$$

where $B$ : revenue requirement:

$a$ : audit cost which is constant per case.

Further, the tax agency must take into account taxpayers' utility optimizing behavior which follows:

$$
\underset{r}{\operatorname{Max}} E U=(1-P) U\left(y_{s}\right)+p U\left(y_{c}\right)
$$

where $E U$ : expected utility;

$U$ : concave utility function. i.e., $U^{\prime}>0, U^{\prime \prime}<0$;

$$
y_{s}=y-T ; \text { and } y_{c}=y-T^{*}-\gamma\left(T^{*}-T\right)
$$

The first-order condition (FOC) to equation (3) is given by:

$$
p \gamma U^{\prime}\left(y_{c}\right)+p^{\prime}(T)\left[U\left(y_{c}\right)-U\left(y_{s}\right)\right]=(1-p) U^{\prime}\left(y_{s}\right)
$$

\section{Three Audit Mechanisms}

The government maximizes social welfare (1) with respect to $p$ subject to its two constraints (2) and (4). We obtain the FOC to this problem as:

$$
\begin{aligned}
& -\int_{0}^{y^{b}} g^{\prime}(e) T^{\prime \prime}(p) d F(y)+\lambda_{1}\left[\int_{0}^{y^{b}}\{a-e(1+\gamma)\} d F(y)\right. \\
& \left.-\int_{0}^{y^{b}}\{1-p(1+\gamma)\} T^{\prime}(p) d F(y)\right]-\lambda_{2}\left[\gamma U^{\prime}\left(y_{c}\right)+U^{\prime}\left(y_{s}\right)\right] \leq 0,
\end{aligned}
$$


where $d=T^{*}-T$, i.e., evaded tax;

$\lambda_{1}, \lambda_{2}:$ the Lagrange multipliers for equations (2) and (4).

Suppose the tax agency divides taxpayers into groups by signals (e.g., schooling year) for income. Across classes, obviously those (e.g., doctors) with stochastically higher income distribution must be audited with a higher chance than otherwise. Within a group, however, individual income is verifiable only with costly audit. How should the tax agency then select whom to audit?

We consider three audit regimes: (1) random audit, i.e., $p^{\prime}(T)=0$; (2) endogenous audit with $p^{\prime}(T)<0$; and (3) deterministic cutoff audit. Under the last rule, if a taxpayer reports above a guideline, she is not audited. Otherwise, she may be subject to audit with $p^{\prime}(T)>0$ is not considered due to envy-driven imitation, i.e., self-selection. By manipulating equations (1) through (5), we derive the followings.

First, in terms of deterring blatant evasion (i.e., $T=0$ ), cutoff audit is the best: endogenous audit is the next best, and random audit is the worst. this is drawn from the condition for internal optima in the FOC (4) and from the secondorder condition (SOC) to equation (3).

Second, we read off the FOC (5) three positive and three adverse impacts of audit: (1) an increase in social welfare; (2) an increase in tax revenue; (3) a direct increase in fines and detected tax; (4) an increase in audit costs; (5) an indirect reduction in fines due to increased deterrence; and (6) a decrease in the expected utility of taxpayers. Coupled with the condition against a corner solution in the FOC (5), it is straightforward to see that audit must be imperfect (i.e., $p<1$ ) as long as it is costly (i.e., $a>0$ ).

Third, if 'absolute risk aversion' (ARA) declines with income as usual, both reported and evaded tax rise with income under random audit. Under endogenous audit, marginal reported (evaded) tax is higher (lower) than under random audit. These are based on comparative statics drawn from equation (4).

Fourth, under cutoff audit, the threshold income $\left(y^{*}\right)$ above which tax-payers report just the guideline $\left({ }^{\prime}\right)$ is determined by

$$
U(y-T)=V(T ; y)
$$

where $T f:$ tax liability at the guidelind $\left(\mathcal{y}^{\prime}\right)$, i.e., $T^{*}\left(y^{\prime}\right)$;

$V(\cdot)$ : indirect utility, i.e., $T=\operatorname{argmax} E U(\cdot)$,

In Figure 1, those with income $y^{*}$ are indifferent between: (1) reporting $y$, paying $T f$, and getting away with evasion; and (2) paying $T\left(y^{*}\right)$ and triggering an uncertain audit. As audit is not a certainty, taxpayers' threshold income should be higher than the guideline. $T$ is greater than $T\left(y^{*}\right)$ and the gap is the risk premium seized by the tax agency. Beyond $y^{*}$, ex ante tax curve $\mathrm{R}$ becomes horizontal. Sanded area $J$ corresponds to total risk premium while shaded area $K$ to revenue loss from high-income taxpayers. 


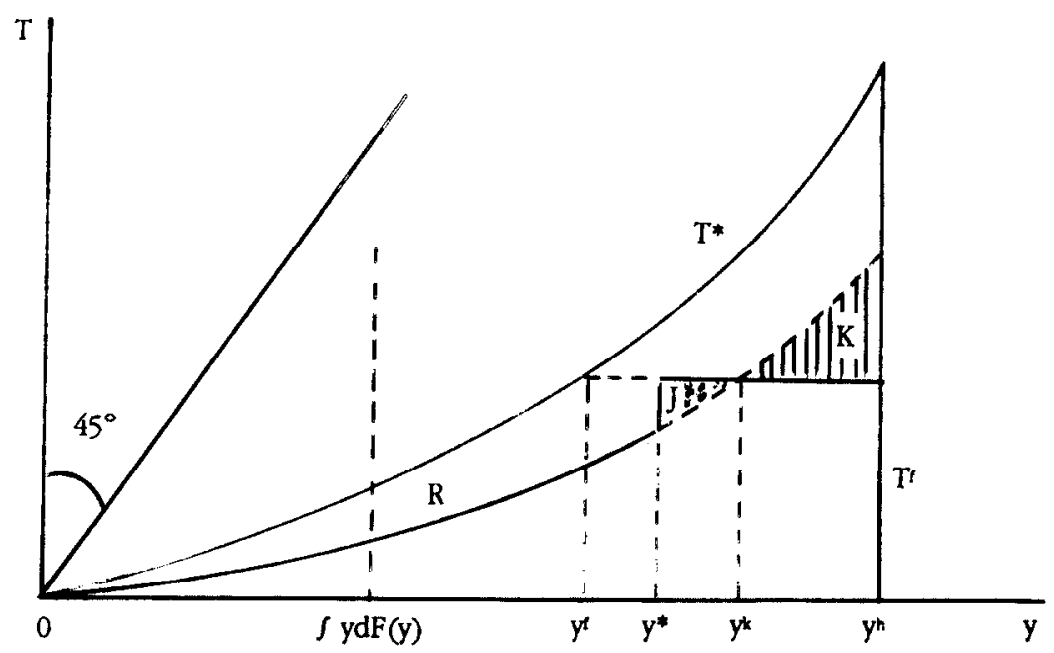

Figure 1. Comparison of Welfare between Tax Audit Mechanisms

Lastly, cutoff audit may be superior to endogenous audit in terms of revenue due to savings in audit resources and expropriated risk premium.5) However, the former is inferior in terms of social welfare as it makes the effective marginal tax schedule discontinuous and thus yields a regressive bias which is punished by social aversion to inequality.

\section{Evaluation of the NTA's Audit Policy}

As above, two aspects favor cutoff audit. First, it saves in audit resources as a selfscreening mechanism. Second, risk is eliminated from high-income earners. Their bookkeeping costs may be conserved as well. Another argument has it that the policy may work against tax corruption by reducing the contacts between taxpayers and tax officials.

Several arguments against cutoff audit are in order: (1) It lowers social welfare by impeding vertical equity; (2) the visibility of the cutoff undermines the cost-saving merit of line drawing (O'Keeffe et al., 1984); (3) Costs of setting and adjusting guidelines may be prohibitive; and (4) Honest but serious riskaverters may overcomply as mentioned earlier.

Finally, in light of Korean business environments, cutoff audit is harmful in the long run, It discourages bookkeeping and subverts the cross-checking visage of tax invoices. Further, it distorts business practices such as fictitious closing-down (Rhee, i990).It keeps non-filers or new businesses from reporting honestly since their 
future liability incrementally hinges on this year's. Lastly, without proper records or books, tax corruption may be rather encouraged.

In conclusion, the audit probability must decline in reported income without truncation. At least, the cutoff must be kept secret. An alternative may base the audit threshold contingent on the ex post distribution of reported tax.

\section{Empirical Evidences}

Empirical studies on tax compliance are not common due to the lack of hard data. Randomly audited tax files are preferable but not available.As an alternative, we select the 1989 FIES. Using the FIES was initiated by O'higgins (1981) and has been since popular.6) Focusing on those with atypically high expenditures relative to income, they infer hidden income of the suspected from the consumption function. Existing works are, however, subject to several critics.7)

We suggest a different approach. Grouping the sample into SELF HHs and PAYE $\mathrm{HHs}$, an income tax payment function is estimated. Our method does not rely on arbitrary assumptions as the existing one. However, the 'self-selection bias' from nonresponse to the FIES and the downward bias from the possibility of false income statement remain, leading to underestimation of the true tax gap.

\section{Data and Variables}

The National Bureau of Statistics (NBS) conducted the FIES of about 4,300 urban HHs monthly in 1989. Participating HHs recorded income by source and expenditures by category. From the data set, we construct two groups of variables: (1) attributes of $\mathrm{HHs}$ or $\mathrm{HH}$ heads; and (2) economic activities of HHs.

The first group includes: SELF as a dummy (versus PAYE) family members);EARNERS (number of earners); SEOUL (whether living in Seoul); OWNER (owner-occupied housing) and LEASE (living in cbonsei) ${ }^{9}$; MALE (maleheaded); YOUNG(HH heads younger than 25-year-old), FORTY (heads in 40s), and OLD (heads older than 50); and PRIMARY (heads with a schooling year of six or below) and COLLEGE (more than 12 years of schooling).

In the second group are four economic variables: INCOME; CONSUMPTION; TAX; and WEALTH. INCOME and CONSUMPTION represent monthoy gross income and consumption expenditures respectively. TAX is the sum of personal income tax and defense tax, a surtax to income tax. ${ }^{10)}$ WEALTH is a proxy for net financial assets and real estates constructed from capital income and imputed rent 


\section{Inferences from Descriptive Statistics}

\section{A. Self-selection}

As participation in the FIES is voluntary, the response rate likely falls with: (1) true income; (2) the proportion of transitory income to total income; and (3) hidden income. As shown in D, we find the first hypothesis convincing. But, our concern lies in the last case where using the FIES would underestimate the tax gap. The response rate is unexpectedly high (80 to $85 \%$ ), higher than the U.K.'s $70 \%$ (Pyle, 1989). Since $34.0 \%$ of the population are SELF HHs while they constitute $35.0 \%$ of participants, the suspected do not seem to have opted out of the survey. ${ }^{11)}$ Rather, SEOUL HHs participate notably less, perhaps due to higher income, busier daily life, or more opportunities to evade tax in Seoul.

\section{B. Non-Filers or Non-Registrants}

By cross-checking the Economically Active Population Survey with the NTA statistics, we obtain a crude estimate of ghosts beyond tax enforcement. Setting aside farm HHs, 1.1 million (32.8\%) of the self-employed did not file tax returns and 1.5 million (89.5\%) temporary employees did not have any NTA record in 1989.12)

\section{C.The Proportion of Households with Positive Income Tax}

Only $53.6 \%$ of the sample paid income tax. The proportion is much higher for PAYE HHs (67.0\%) than for SELF HHs (28.8\%). Comparing these figures with the NTA data reveals some discrepancies primarily because of multi-earner HHs, but preserves the qualitative conclusion. Those with zero tax are not necessarily poor. Among the top $10 \%$ of income distribution, $16.7 \%$ pay no income tax. This is in a stark contrast to the NTA data, according to which only $4.4 \%$ of top $13.3 \%$ bracket paid no income tax. Thus, many rich people must have cheated blatantly.

\section{The Ratio of Income Tax to Income}

The ratio $(2.09 \%)$ of average income tax to mean income tax to mean income (ATR) in the FIES is lower than that $(2.76 \%)$ of income tax collection to GNP. The reverse would be normal. Nonparticipation of the rich seems to provide a clue to the puzzle. ${ }^{13)}$ SELF HHs' ATR is only $1.08 \%$ or two-fifths of PAYE HHs' $2.63 \%$ despite virtually identical income. Since SELF HHs are not treated preferably over PAYE HHs, the former's low ATR indicates the possibility of tax sheltering or tax evasion. We can not however distinguish between the two possibilities as non-taxable income, taxexempt income, and deductions are unknown. 
〈Table 1〉 Means of Selected Variables by Household Group

in won

\begin{tabular}{lcccccccc}
\hline & $\begin{array}{c}\text { INCOME } \\
(\mathrm{A})\end{array}$ & $\begin{array}{c}\text { TAX } \\
(\mathrm{B}) \mathrm{a}\end{array}$ & $\begin{array}{c}\text { ATR } \\
(\mathrm{B} / \mathrm{A})\end{array}$ & $\begin{array}{c}\text { RATIO } \\
\text { TAX }>00^{\mathrm{b}}\end{array}$ & $\begin{array}{c}\text { DSP INCOME } \\
(\mathrm{C})^{\mathrm{c}}\end{array}$ & $\begin{array}{c}\text { CONSUM } \\
(\mathrm{D})\end{array}$ & $\begin{array}{c}\text { APC } \\
(\mathrm{D} / \mathrm{C})\end{array}$ \\
\hline All HHs & 733,955 & 15,325 & $2.09 \%$ & .536 & 671,285 & 535,161 & .797 \\
SELF HHs & 732,660 & 7,882 & $1.08 \%$ & .288 & 682,860 & 570,563 & .836 \\
PAYE HHs & 734,652 & 19,322 & $2.63 \%$ & .670 & 665,052 & 516,099 & .776 \\
PERMANENT & 754,292 & 20,769 & $2.75 \%$ & .705 & 681,475 & 526,468 & .773 \\
TEMPORARY & 498,396 & 2,046 & $.41 \%$ & .253 & 467,496 & 391,369 & .837 \\
\hline & GRS CONS & WEALTHe & OWNER & LEASE & SEOUL & MEMBERS & EARNERS \\
\hline All HHs & 669,098 & 13,010 & .45 & .33 & .31 & 4.03 & 1.37 \\
SELF HHs & 719,063 & 14,284 & .49 & .27 & .32 & 4.08 & 1.28 \\
PAYE HHS & 642,199 & 12,324 & .43 & .37 & .30 & 4.00 & 1.43 \\
PERMANENT & 657,256 & 12,728 & .43 & .37 & .30 & 3.99 & 1.41 \\
TEMPORARY & 461,069 & 7,459 & .39 & .33 & .26 & 4.14 & 1.61 \\
\hline & MALE & COLLEGE & PRIMARY & AGE & YOUNG & FORTY & OLD \\
\hline All HHs & .87 & .23 & .12 & 38.4 & .04 & .26 & .15 \\
SELF HHs & .83 & .21 & .14 & 41.3 & .03 & .29 & .21 \\
PAYE HH & .88 & .25 & .11 & 36.9 & .05 & .25 & .11 \\
PERMANENT & .89 & .27 & .09 & 36.6 & .05 & .24 & .10 \\
TEMPORARY & .82 & .02 & .40 & 40.5 & .01 & .32 & .28 \\
\hline
\end{tabular}

a: the sum of personal income tax and defense tax to income tax;

b: the proportion of HHs with positive income tax out of all HHs;

c: monthly gross income less non-consumption expenditures;

d: the sum of consumption expenditures and imputed rents;

e: the present value (in thousand won) of the infinite stream of net capital income and imputed rents computed by an annual discount rate of $10 \%$.

\section{E. Consumption}

SELF HHs spend decidedly more than PAYE HHS from identical income, i.e.,the ratio of consumption to disposable income is higher for the former than for the latter. The difference is a puzzle. Two hypotheses are: (1) SELF HHs financed some consumption at business expenses; or (2) They understated income in the FIES in accordance with tax returns. Further, SELF HHs exhibit a more affluent consumption pattern. For example, they spend less on 'food and beverages,' but more on 'education, culture, and recreation' and 'personal transportation.' SELF HHs live in more expensive housing than PAYE HHs as well. ${ }^{14)}$ 


\section{F. Other Attributes}

SELF HHs are the wealthiest, the most likely to live in owner-occupied housing and in Seoul, and have the fewest earners per HH. Permanent employee HHs are the youngest, the best educated, the most likely to be male-headed, and have the fewest family members. Temporary employee HHs are the poorest, the least educated, the most likely to be headed the female and by the elderly, the least likely to live in owner-occupied housing and in Seoul. They have the most earners and family members. Table 1 summarizes the descriptive statistics.

\section{Estimation Methods}

Two econometric approaches are adopted. First, we use standard parametric methods: (1) the OLS (log-linear); (2) the probit; and (3) the Heckman's two-stage selfselection correction method (Heckman, 1976). The probit model seems imperative in view of a large fraction (46.4\%) of censored observations at zero tax. The Heckman method is due to the possibility that HHs may have made two separate decisions sequentially with regard to: (1) whether to file the tax return;and (2) how much income to report conditional on filing.

We also try the Nadaraya-Watson kernel estimator (Nadaraya, 1964; Watson, 1964), a state of art 'nonparametric estimation' (NPE) technique. Its motivation is twofold. First, the sensitivity of parametric results can be checked. Moreover, NPE addresses some drawbacks of parametric estimation. The income tax function is likely nonlinear due to graduated tax rates, tax thresholds, and reporting guidelines. Specifying a particular function, we may cause a bias. We find NPE helpful against these problems. ${ }^{15}$ )

\section{Estimation Results}

\section{A. Who Pays Income Tax?}

Since about a half of HHs pay no income tax, we need to examine who they are. In Table 2, probit results are outlined. The tax-paying probability is higher or rises with income more rapidly for PAYE HHs than for SELF HHs. PAYE HHs are more likely to pay income tax than SELF HHs by .374. An extra income of 1,000 won raises the former's probability by .0037 , higher than the latter's by .0005 .

Another impotant variables are housing tenure choice and educational attainment. The owner-occupied HHs' tax-paying probability is higher than LEASE HHs by .06 . The latter's is in turn higher than rental HHs' by .112. Those with some college education are more likely to pay tax than the next best educated by .066 . The probability of the least educated is lower than the middle group by .144. Education gets taxpay- 
〈Table 2〉 Parametric Estimation Results of the Income Tax Function

Absolute t-values are in parentheses. After initial regressions with the whole sample, outliers ( $2.4 \%$ to $2.6 \%$ of the sample) with the value of studentized residuals above two are excluded from each model. This follows the suggestion of Belsley et al. (1980). Once outliers are taken out, the residual plot shows no serious heteroscedasticity

\begin{tabular}{|c|c|c|c|c|}
\hline MODEL & PROBIT & OLS FOR AlL & OLS FOR TAX $>0$ & HECKMAN \\
\hline INTERCEPT & $-4.46(34.0)$ & $-21.09(62.3)$ & $-8.07(57.4)$ & $-16.93(28.0)$ \\
\hline In INCOME & $.34(33.3)$ & $1.96(74.9)$ & $1.29(120.3)$ & $1.66(61.5)$ \\
\hline SELF & $.70(3.8)$ & $16.01(36.6)$ & $6.47(23.0)$ & $5.76(20.1)$ \\
\hline In INCOME*SEIF & $-.14(9.7)$ & $-1.52(45.8)$ & $-.55(26.4)$ & $-.61(28.9)$ \\
\hline In WEALTH & $-.01(3.6)$ & $-.03(3.3)$ & $-.02(6.7)$ & $-.03(9.5)$ \\
\hline In MEMBERS & $-.08(3.5)$ & $-.32(5.4)$ & $-.20(7.9)$ & $-.29(11.3)$ \\
\hline EARNERS & $.10(10.5)$ & $.18(7.3)$ & $-.21(20.1)$ & $-.09(6.7)$ \\
\hline MALE & $.07(3.5)$ & $.41(7.7)$ & $.25(9.6)$ & $.34(13.0)$ \\
\hline SEOUL & $.16(11.3)$ & $.18(4.8)$ & $-.61(39.1)$ & $-.44(22.6)$ \\
\hline OWNER & $.71(15.4)$ & $2.37(20.1)$ & $.83(16.5)$ & $1.67(22.1)$ \\
\hline LEASE & $.43(9.6)$ & $1.16(10.1)$ & $.36(7.3)$ & $.89(14.6)$ \\
\hline YOUNG & $-.26(7.9)$ & $-.73(8.4)$ & $-.04(1.0)$ & $-.39(8.4)$ \\
\hline FORTY & $.04(2.4)$ & $.28(6.8)$ & $.21(12.3)$ & $.25(14.4)$ \\
\hline OLD & $.08(4.0)$ & $.41(7.8)$ & $.35(15.5)$ & $.44(18.6)$ \\
\hline PRIMARY & $-.41(20.1)$ & $-1.40(25.8)$ & $-.22(8.1)$ & $-.76(16.9)$ \\
\hline COLLEGE & $.22(14.2)$ & $1.19(29.6)$ & $.54(34.5)$ & $.76(35.6)$ \\
\hline MILLS & $\mathrm{N} / \mathrm{A}$ & N/A & N/A & $7.76(15.1)$ \\
\hline Adjusted $R^{2}$ & $\mathrm{~N} / \mathrm{A}$ & .3914 & .5328 & .5362 \\
\hline SSR & N/A & 641,552 & 30,984 & 30,736 \\
\hline F-value & N/A & 2,150 & 2,005 & 1,906 \\
\hline Chow Statistic ${ }^{a}$ & $\mathrm{~N} / \mathrm{A}$ & 127.6 & 91.1 & 85.2 \\
\hline LLK for Normal & $-28,816$ & $\mathrm{~N} / \mathrm{A}$ & $\mathrm{N} / \mathrm{A}$ & $\mathrm{N} / \mathrm{A}$ \\
\hline LR Statistic ${ }^{b}$ & 20,408 & N/A & $\mathrm{N} / \mathrm{A}$ & N/A \\
\hline Correctly Predicted & $74 \%$ & $\mathrm{~N} / \mathrm{A}$ & $\mathrm{N} / \mathrm{A}$ & N/A \\
\hline
\end{tabular}

a: From the Chow test of equality between SELF and PAYE HHs pursuant to Chow (1960)

b: The log-likelihood ratio test statistic is calculated by $-2\left(L_{0}-L_{m}\right)$ which asymptotically follows $\mathrm{a}_{\mathrm{x}_{4}}$ distribution, where $L_{0}$ is the LLK evaluated at the starting point, $L_{m}$ is the LLK at convergence, and $q$ is the number of restricted variables (Kmenta, 1986).

ers on record.

The tax-paying probability goes up with EARNERS. It declines with MEMBERS presumably due to personal deductions which rise with the number of dependents. Seoul residents are more likely to pay tax than local HHs by .052 . YOUNG HHs' prob- 
〈Table 3〉 Estimates of the Income Elasticity of Income Tax Payment

In parentheses are absolute t-values for parametric estimates or the average elasticities divided by the standard deviations of the point elasticities for NP estimates

\begin{tabular}{lcr}
\hline MODEL & SELF HHs & HIRED HHs \\
\hline & \multicolumn{2}{c}{ Parametric Estimates } \\
OLS for All HHs & $.436(45.8)$ & $1.959(74.9)$ \\
OLS for TAX $>0$ only & $.737(26.4)$ & $1.290(120.3)$ \\
2-Stage Heckman & $1.050(28.9)$ & $1.662(61.5)$ \\
\hline & \multicolumn{2}{c}{ Nonparametric Estimates } \\
For all HHs & $.880(1.4)$ & $1.620(1.6)$ \\
For TAX $>0$ only & $.648(1.4)$ & $.941(2.4)$ \\
\hline
\end{tabular}

ability is the lowest among age groups. The gender of HH heads is not significant. Capital income is less susceptible to taxation than labor income. Strikingly, an additional 1,000 won of nonhuman wealth reduces the probability by .00003 , confirming lax tax enforcement against capital income. ${ }^{16)}$

\section{B.Income Elasticity of Income Tax Payment (IET)}

Income tax must rise with income at an increasing rate, i.e., the IET must be greater than one under a progressive tax schedule (In 1989, the marginal income tax rate graduated with 8 brackets from $5 \%$ up to $50 \%$ ). Table 2 presents parametric estimation results. The 'Chow test' statistic shows SELF HHs are far different from PAYE HHs in tax-paying behavior. Since the 'inverse Mills ratio' indicates a significant selfselection bias, Heckman estimates after accounting for the bias deem more reliable.

In Table 3, we compare the estimated IET by group, including the NPE results. In every case, the PAYE HHs' IET is higher than SELF HHs'. Parametric estimates are greater than one for PAYE HHs, but range between .44 and 1.05 for SELF HHs, hinting tax-saving activities of high-income SELF HHs. As predicted in Section 2, the NTA's reporting guidelines are suspected to lower the ex post elasticity of SELF HHs. Unexpectedly, PAYE HHs' IET declines when measured with tax-paying HHs alone implying that many high-income PAYE HHs pay no tax.

Figure 2 shows the curves fitted by NPE. The PAYE HHs' curve always lies above SELF HHs': PAYE HHs pay more tax than the other at any income level. This seems a benefit of NPE which does not restrict the two curves to meet somewhere. PAYE HHs' curve is also steeper than SELF HHs'. Figure 3 depicts the partial derivatives (i. e., IET) estimated by NPE. They vary freely exhibiting another privilege of NPE. For PAYE HHs, the IET is lower at both tails. The pause at a lower tail may reflect exemptions and deductions. The dip at a higher one may be due to rich employees with 


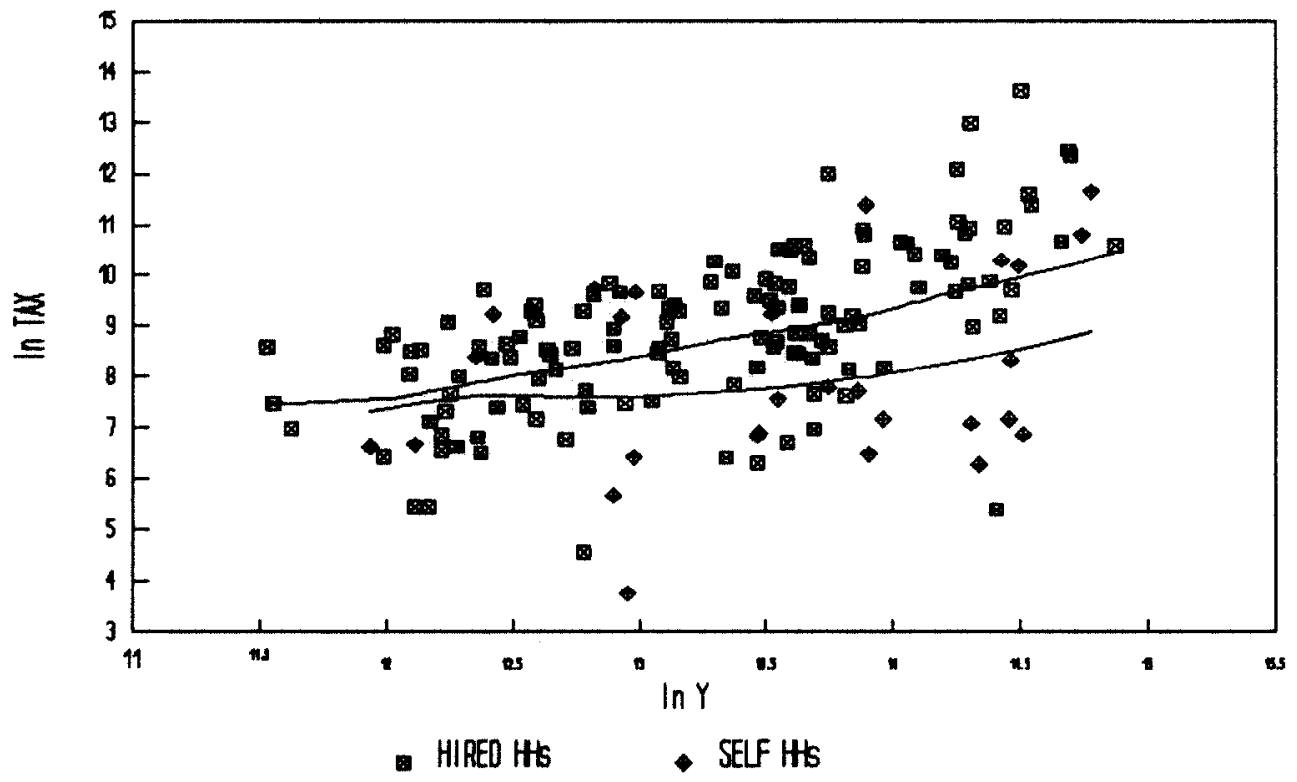

Figure 2. Nonparametric Curves of Income Tax Payment

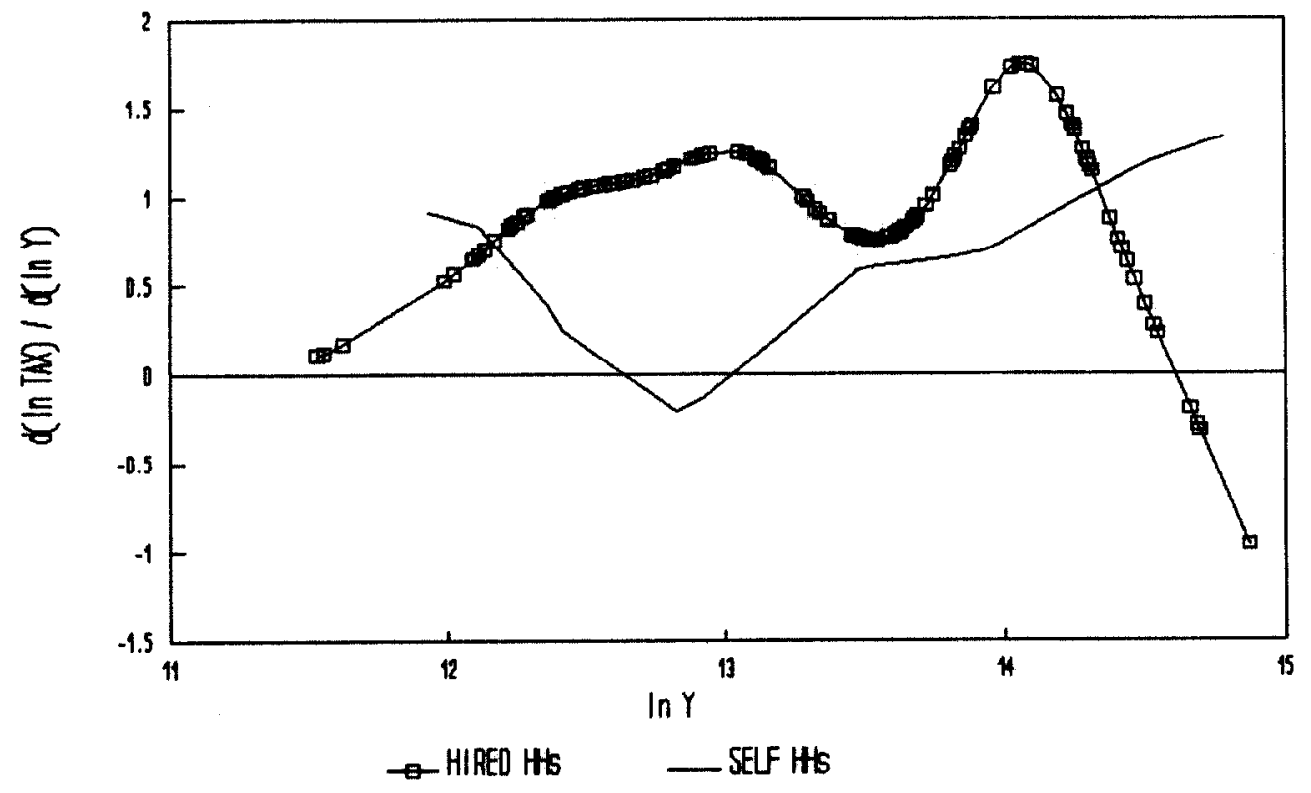

Figure 3. Nonparametric Income Elasticity of Income Tax Payment 
〈Table 4 \stimates of the Income Tax Gap for Self-employed Households

For the tax gap estimates of SELF HHs with TAX $>0$, the mean values of tax-paying HHs are used in formula (9). For the tax gap from NPE, we use the vertical distance between two fitted curves at the mean income of SELF HHs instead of using the dummy and the interaction term

\begin{tabular}{|c|c|c|c|c|c|c|}
\hline & & \multicolumn{3}{|c|}{ PARAMETRIC ESTIMATES } & \multicolumn{2}{|c|}{ NP ESTIMATES } \\
\hline & & AlL & $\mathrm{TAX}>0$ & HECKMAN & AlL & $\operatorname{TAX}>0$ \\
\hline \multirow[t]{2}{*}{ AVG INCO TAX } & (A) & 7,882 & 27,368 & 7.882 & 7,882 & 27,368 \\
\hline & & & \multicolumn{2}{|c|}{ REPRESENTATTVE } & $\mathrm{HH}$ & \\
\hline TAX GAP & (B) & 11,929 & 4,573 & 6,761 & 10,293 & 3,585 \\
\hline TRUE TAX & $(A+B)$ & 19,811 & 31,941 & 14,643 & 18,175 & 30,953 \\
\hline \multirow[t]{2}{*}{ GAP RATIO } & $(B / A+B)$ & .602 & .143 & .462 & .566 & .116 \\
\hline & & \multicolumn{5}{|c|}{ AVERAGE OF ALL HHs } \\
\hline TAX GAP & (C) & 13,195 & 4,900 & 7,638 & 13,360 & 6,409 \\
\hline TRUE TAX & $(A+C)$ & 21,077 & 32,268 & 15,520 & 21,242 & 33,777 \\
\hline GAP RATIO & $(\mathrm{C} / \mathrm{A}+\mathrm{C})$ & .626 & .152 & .492 & .629 & .190 \\
\hline
\end{tabular}

high capital income. The comverse holds true for SELF HHs: the IET around the mean income is much lower than otherwise. The middle basin may be attributed to the reporting guidelines.

\section{Other Factors}

In Table 3, residential choice and education are again the most meaningful factors. Owner-occupied HHs pay $78 \%$ more income tax than chonsei HHs, who in turn pay 89\% more than rental HHs. Though the better educated may engage more in dexterous tax sheltering, the latent adverse effect of education is dominated by its beneficial effect on compliance. Note that SEOUL HHs are more likely to pay tax but they pay less than local HHs by 44\%. This prompts two hypotheses: (1) Higher living expenses in Seoul are reflected in deductions; or (2) SEOUL HHs pay some tax just above a reasonable minimum and seek more legal sheltering.

Tax payment increases with the age of $\mathrm{HH}$ heads. Three explanations are available: (1) The chance of taxpayer identification grows with age; (2) The younger are more resistant to the tax system according to some surveys; (3) The older are more risk averse. Male-headed HHs pay more. This may be because female heads tend to work in low-profile jobs. MEMBERS adversely affects tax payment, but EARNERS is not critical. Finally, WEALTH hardly affects income tax payment: its effect is neither economically nor statistically significant. 


\section{Income Tax Gap between Groups}

Table 4 presents two measures of an income tax gap. One is a gap between representative HHs of each group. The other is a mean of the vertical distance between fitted curves of the two groups. The results are moderately sensitive to estimation methods and specifications. The income tax gap of a representative SELF HH is estimated between $46.2 \%$ to $60.2 \%$ of its tax liability. The averages of the simulated tax gap are a bit higher in all cases: $49.2 \%$ to $62.9 \%$. The reason being, the tax gap tend to widen with income, as predicted in Section 2 . Taken together with the proportion and tax payment of each group, the estimates yield a revenue loss equivalent to 17 . $7 \%$ to $30.4 \%$ of income tax collection

\section{Concluding Remarks}

NTA's current cutoff audit yields lower social welfare due to a regressive bias than endogenous audit. It also hinders self-compliance. Therefore, the audit probability must decrease with reported income without truncation.

Many self-employed and temporary employees are not identified by the NTA. Overall, the effective tax rate depends on the income source, i.e., tax enforcement is ineffective to income from self-employment and capital. In particular, the SELF HHs' IET is very low around the mean income which seems attributable to the reporting guideline. The estimated income tax gap of SELF HHs, rising with income, amounts to a significant portion of income tax revenue.

The scope for further study is ample. Above all, modification of the enforcement objective may warrant valuable insights. For example, the tax agency may minimize the fraction of tax evaders among taxpayers or society may assign different weights to the utility between compliers and cheaters.

Second, we assumed that the tax agency can precommit to a deterministic audit rule. This may be naive as the horizon of elective representatives or the head of the agency is finite. The 'time-inconsistency' (Kydland and Prescott, 1977) problem in tax enforcement is worth pursuing.

Finally, in the empirical analysis, high-income HHs with no income tax need be examined in detail. Treating temporary employee HHs separately from permanent employee HHs seems rewarding as well. In addition, it is worthwhile to run NPE with varying band-widths or different kernels for robust results. ${ }^{17}$ )

\section{Endnotes}

1) The Economic Planning Board (EPB) reportedly estimates the size of the irregular sector as 19\% of GNP in 1988 (Seoul Daily Economy, 1990. 3. 26). According to Choi (1987: p. 192), the 'Committe on the Development of Tax System' (1985) assesses the compliance rate-in 


\section{The Korean Journal of Policy Studies}

terms of tax payment-for labor income, personal business income, and capital income as $70.4 \%, 38.7 \%$, and $29.7 \%$,respectively in 1981 . Some estimates that less than $15 \%$ of real estate rental income is reported (Yun, 1992).

2) For the details of eight arguments against the above 'burn them in oil'solution, see Bahk (1992).

3) Such treatment would lead to laxer enforcement because a lower weight to the utility of tax evaders implies sterner measures against tax evasion. With evaders' utility completely ignored, we would get back to the Becker's world.

4) Adelstein (1978) notes, "innocent defendants may be persuaded to accept a proffered plea bargain and subject themselves to sanction for the crime which they did not commit due to the pressures of the bargaining situation."

5) This feature has been shown by several studies (Grossman and Katz, 1983; Reinganum and Wilde, 1985; Scotchmer, 1987; Cremer et al., 1990; Kaplow and Shavell, 1991).

6) For instance, Dilnot and Morris (1982), Carter (1984), Smith and Wied-Nebbeling (1986), Smith et al. (1986), and O'Higgins (1989).

7) These include: (1) Evaders are less likely to respond to the survey; (2) Their estimates are vulnerable to errors as they rely on indirect inference; (3) Their key assumption-expenditures are reported honestly but income is deliberately understated-is erratic; (4) They use arbitrary standards to identify suspicious $\mathrm{HHs}$; and (5) Their consumption function is too naive.

8) PAYE HHs, permanent or temporary worker HHs, are those with wages or salaries being the primary income source. The distinction between the two subgroups is whether a main earner works on a longer than one-month contract.

9) Chonsei refers to rental or lease of a house by deposit alone (without rent). Housing type other than OWNER or LEASE is 'monthly rental.'

10) Before being abolished in 1991, defense tax was levied on top of income tax amount (less tax credit) at a rate of $10 \%$ or $20 \%$.

11) This is a bit surprising. According to Kemsley (1975), the self-employed are significantly underrepresented in the U.K. Family Expenditure Survey.

12) As income earned by temporary employees is taxed separately at a flat rate of the lowest $5 \%$ after deduction, it is doubtful whether missing temporary workers carries any significance.

13) Only $1.2 \%$ of PAYE workers paid $21 \%$ of withheld income tax and top $1.4 \%$ global income taxpayers contributed $24 \%$ of global income tax. If many of highest-income HHs missed the survey, the ATR must be considerably lower than actual.

14) According to O'Higgins (1980), despite their apparently low income, the U.K. selfemployed appear to have a higher standard of living than PAYE HHs when measured by ownership of consumer durables.

15) For details of Nadaraya-Watson kernel estimation models, see Silverman (1986), Eubank (1988), Ullah (1989), and Bahk (1992).

16) Pseudonym financial transactions, the informal financial market, and rental income are generally blamed for this.

17) We use the standard 'Gaussian kernel.' Among others are: Epanechnikov (quadratic or 
optimal), biweight, triangular, rectangular (uniform), and minimum variance kernel. For band-width, we follow Bierens (1987).

\section{References}

Adelstein, R.P. (1978), "The Plea Bargain in Theory: A Behavioral Model of the Negotiated Guilty Plea," Soutbern Economic Journal, Vol. 44.

Bahk, J. (1992), Interdependent Behaviors of Taxpayers and Tax Officials: Models and Some Evidences from Korea, Ph.D. Thesis, Harvard University, Cambridge, MA, USA.

Becker, G.S. (1968), "Crime and Punishment: An Economic Approach," Journal of Political Economy, Vol. 76, No. 2.

Belsley, D., E. Kuh, and R. Welsch (1980), Regression Diagnostics, Identifying Influential Data and Sources of Collinearity, Wiley, NY, USA.

Bierens, H. (1987), "Kernel Estimation of Regression Function" in Advances in Econometrics edited by T. Bewly, Cambridge University Press, NY, USA.

Carter, M (1984), "Issues in the Hidden Economy-A Survey," Economic Record, Vol. 60, No. 170.

Chang, S.W. (1991), A Study on Operation of Value Added Tax and Income Tax on Individual Businesses in Korea, Mimeo, International Tax Program, Harvard Law School, Cambridge, MA, USA.

Choi, K. (1987), A Study of the Underground Economy in Korea: Theoretical Approaches, Empirical Evidences, and Policy Implications, Korea Economic Research Institute, Seoul, Korea (in Korean).

Chow, G.C. (1960), "Tests of Equality between Sets of Coefficients in Itwo Linear Regressions," Econometrica, Vol. 28, July.

Chu, C.Y. Cyrus (1990), "Plea Bargaining with the IRS," Journal of Public Economics, Vol. 41.

Committee on the Development of Tax System (1985), Report on the Development of Tax System, The Ministry of Finance, Seoul, Korea (in Korean).

Cremer, H., M. Marchand, and P. Pestieau (1990), "Evading, auditing, and Taxing: The EquityXimpliance Tradeoff," Journal of Public Economics, Vol. 43.

Dilnot, A. and C. Morris (1982), "What Do We Know about the Black Economy?"in The Underground Economy in the U.S. and Abroad edited by V. Tanzi, Heath and Company, Lexington, MA, USA.

Eubank, R. (1988), Spline Smoothing and Nonparametric Regression, Wiley, NY.

Grossman, G. and M. Katz (1983), "Plea Bargaining and Social Welfare," American Economic Review, Vol. 73, No. 4.

Heckman, J. (1976), "The Common Structure of Statistical Models of Truncation, Sample Selection and Limited Dependent Variables and a Simple Estimator for Such Models," Annals of Economic and Social Measurement, Vol. 5.

Kaplow, L. and S. Shavell (1991), Optimal Law Enforcement with Self-reporting of Bebavior, Discussion Paper No. 95, Program in Law and Economics, Harvard Law School, Cambridge, MA, USA.

Kemsley, W. (1975), "Family Expenditure Survey: A Study of Differential Response Based on a Comparison of the 1971 Sample with the Census," Statistical News No. 31. 
Kmenta, J. (1986), Elements of Econometrics, 2nd ed., Macmillan Publishing Company, NY, NY, USA.

Kydland, F.E. and E.C. Prescott (1977), "Rules Rather Than Discretion: The Inconsistency of Optimal Plans," Journal of Political Economy, Vol. 85, no. 3.

Nadaraya, E. (1964), "On Regression Estimators," Theory of Probability and Applications, Vol. 9.

NTA (1990), Statistical Yearbook of National Tax, The National Tax Administration, Seoul, Korea.

O'Higgins, M. (1980), Measuring the hidden economy: A review of evidence and methodologies, Outer Circle Policy Unit, London, UK.

O'Higgins, M. (1981), "Tax Evasion and the Self-employed-An Examination of the evidence-II," British Tax Review, No. 6.

O'Higgins, M. (1989), 'Assessing the Unobserved Economy in the United Kingdom" in The Underground Economies edited by E.L. Feige, Cambridge University Press, NY, NY, USA.

O'Keeffe, W., W. Viscusi, and R. Zeckhauser (1984), "Economic Contests: Comparative Reward Schemes," Journal of Labor Economics, Vol. 2, No. 1.

Pyle, D. (1989), Tax Evasion and the Black Economy, The MacMillan Press, London, UK.

Reinganum, J.F. and L.L. Wilde (1985), "Income Tax Compliance in a Prircipal-Agent Framework," Journal of Public Economics, Vol. 26.

Rhee, W.T. (1990), A Research on the Tax Administration in Korea, Korea Economic research Institute, Seoul, Korea (in Korean).

Scotchmer, S. (1987), "Audit Classes and Tax Enforcement policy: Economic Analysis of Taxpayer Compliance," American Economic Review, Vol. 77. No. 2.

Silverman, B. (1986). Density Estimation for Statistics and Data Analysis, Chapman and Hall, NY,NY, USA.

Smith, C. Pissarides, and G. Weber (1986), "Evidence from Survey Discrepancies" in Britain's Shadow Economy by S. Smith for The Institute for Fiscal Studies, Clarendon Press, Oxford, UK.

Smith, C. and S. Wied-Nebbeling (1986), "The Shadow Economy in Britain and Germany," Anglo-German Foundation for the Study of Industrial Society, George Over Ltd., London, UK.

Ullah, A. (1989), "Nonparametric estimation and Hypothesis Testing in Econometrics Models" in Semiparametric and Nonparametric Econometrics edited by A. Ullah, Physica-Verlag, Heidelberg, Germany.

Watson, G. (1964), "Smooth Regression Analysis," Sanikbya, Series A 26:15.

Yun, K. (1992), "Direct Taxation" in Public Finance in Korea edited by K. Choi et al., Seoul National University Press, Seoul, Korea. 